\title{
Geopolitical genetics: claiming the commons through species mapping
}

\author{
Lisa M. Campbell ${ }^{1}$, Matthew H. Godfrey ${ }^{2}$
}

\begin{abstract}
:
Genetic techniques are increasingly employed in the field of conservation biology, and sea turtle conservation is no exception. Our understanding of sea turtle biology, and particularly of sea turtle migrations and population structures, has increased through genetic analyses that 'match' turtles found in various and often widely distributed habitats (e.g. nesting beaches, foraging grounds, migratory corridors). This relatively recent technological development has implications for how sea turtles are conceived, both as resources and as objects of conservation. Traditionally, turtle populations have been attached to particular nesting beaches, and most conservation efforts have focused on these discrete geographic locations (sometimes including off-shore waters), and have been undertaken by the state. The more complete understanding of relationships among turtles found in geographically disparate areas, achieved via genetic analysis, can take conservation beyond the beaches and territorial waters of individual states. Nesting populations can now be linked to foraging populations sometimes hundreds of kilometers distant. In this paper, we explore the implications of genetic analysis for sea turtle conservation, the scale at which it is undertaken, and the variety of actors with competing interests in it. We focus on the case of hawksbill sea turtles in the Caribbean Sea. Conflicts over hawksbill conservation have spurred genetic analysis and genetic analysis has been applied in attempts to resolve those conflicts. We are particularly interested in the way genetic information encourages the scaling up of sea turtle conservation, and how it simultaneously strengthens and weakens claims of individual nation states, obscures claims of local level actors, and strengthens claims of external actors. We draw on political ecology, science studies, and common pool resource theory to explore these transitions and their consequences.
\end{abstract}

Key words: science, sea turtles, ocean commons, political ecology

\footnotetext{
${ }^{1}$ Nicholas School of Environment, Duke University, 135 Duke Marine Lab Road, Beaufort NC, USA

${ }^{2}$ North Carolina Wildlife Resources Commission, 1507 Ann Street, Beaufort NC, USA
} 


\section{INTRODUCTION}

Contemporary wildlife conservation involves debates and decisions about rights to wildlife as resources (Brockington, Igoe, and Schmidt-Soltau 2006), the scale at which wildlife should be managed (Brosius and Russell 2003), and the role of science in dictating conservation policy (Lackey 2007). In this paper, we use the case of sea turtle conservation to explore the relationship between these concepts, and how arguments made about one issue can further goals on others. We specifically explore the implications of recent advances in genetic analysis for sea turtle conservation, the scale at which it is undertaken, and what this implies for the rights of various stakeholders to determine how sea turtles should be managed. Turtle conservationists have increasingly called for the consideration of sea turtles as a regionally or internationally 'shared resource,' to be managed as such (e.g. MTSG 1995; Frazier 2000), but until recently, there were few data available to describe the precise nature of such sharing. Genetic analysis has changed this. While genetic analysis of sea turtle populations is now widespread, we focus on the case of hawksbill sea turtles in the Caribbean Sea, where conflicts over hawksbill conservation have spurred genetic analysis and where genetic analysis has been applied in attempts to resolve those conflicts. We explore how efforts to define ownership of sea turtles, and in particular to move away from local or national and towards regional or international management, can be supported with use (and misuse) of genetic data. We draw on common pool resource theory, political ecology, and science studies and to explore these transitions and their consequences.

As with other species categorized as 'charismatic mega-fauna', sea turtle conservation is highly politicized (Bjorndal and Bolten 2003; Meylan 1998; Mrosovsky 1983; Mrosovsky 1997; Webb and Carrillo 2000; Broderick et al. 2006), in part because sea turtles hold wide public appeal and are valued in a variety of ways (Campbell 2003; Campbell and Smith 2006). Historically, and up until as recently as the 1970s, sea turtles were widely used for their meat, eggs, shell, skins, and oils (Frazier 2003; Campbell 2003). Much of this changed in the 1960 s and 1970s, based on concerns about population declines and with the emergence of new forms of environmentalism in North America and Europe (McCormick 1989). Through a variety of international (e.g. Convention on International Trade in Endangered Species [CITES], 1975) and national (e.g. the US Endangered Species Act, 1970) agreements and laws, the legal use of and trade in sea turtles and their products was curtailed in many parts of the world. Restrictions on use have continued since the 1970s, through new formal agreements (e.g. the 2002 Inter-American Convention for the Conservation of Sea Turtles [Campbell, Godfrey, and Drif 2002]), bilateral pressure on particular nations to live up to existing agreements (e.g. pressure by the US on Japan to remove its CITES reservation on trade in hawksbill turtles [Campbell 2002], discussed further below), and through incentive programs designed to encourage alternative uses of sea turtles. For example, international NGOs are active in promoting protection of sea turtles and eliminating consumptive use, often with 
corresponding promotion of so-called non-consumptive use ${ }^{3}$ via ecotourism (e.g. the Ocean Conservancy's SEE turtles program, http://www.oceanconservancy.org/site/PageServer?pagename=see_turtles; WWF's evaluation of use options for turtles [Troëng and Drews 2004]).

In spite of conservation efforts made over the past 40 years, six out of seven species of sea turtles are classified as being in some level of endangerment on the IUCN's Red List (the seventh is in the category of 'data deficient'). However, although the Red List aims to provide "the most objective, scientifically-based information on the current status of globally threatened biodiversity" (www.iucnredlisit.org), the red listing process has been controversial for sea turtles. While controversy is linked to a number of issues associated with listing (Godfrey and Godley 2008; Mrosovsky 2003; Seminoff and Shanker 2008), of interest here is scale, and whether or not a global categorization of endangerment is appropriate for such widely distributed species. At a regional scale, for example, some populations are believed to be declining (leatherbacks in the Pacific [Spotila et al. 2000]) while others are believed to be increasing (leatherbacks in the Atlantic [Turtle Expert Working Group 2007]). Within regions, nesting trends vary between different countries and even between beaches within countries. In this context, global assessments of threat may not be the most informative.

The question of the appropriate scale at which sea turtle populations should be conceptualized is central not just to the Red List process, however, but to current debates about sea turtle conservation more generally (Campbell 2007), both policy and practice. In policy, there is an exiting tension in statements made by organizations like the Marine Turtle Specialist Group (MTSG) of the World Conservation Union (IUCN), that on one hand advocates regional or international approaches while one the other encourages community based approaches (Frazier 2000; Frazier 1999; Campbell, Godfrey, and Drif 2002). In practice, contemporary conservation varies across nation states. Although the international focus of sea turtle conservation has moved towards strict protection, sea turtles are still used consumptively, both as adults and eggs, in many nations with jurisdiction over sea turtles nesting on domestic beaches and found within territorial waters (Campbell 2003; 2007). In regions like the Caribbean, where the jurisdictions of many nations co-exist and sometimes overlap in a relatively small geographic area, the full spectrum of approaches to sea turtle conservation can be found, ranging from strict protection (e.g. US Virgin Islands), to small-scale fisheries (e.g. Turks and Cacios Islands), to a commercial sea turtle farm in Cayman Islands (Campbell et al. in press). In this context, the contrasting approaches to conservation at the international, regional, national, and local levels are striking. Further, as highly migratory animals often traversing hundreds of kilometers between nesting and foraging areas, contrasting approaches to conservation can become conflicting as sea turtles move across social-political

${ }^{3}$ (Meletis and Campbell 2007) critique the concept of non-consumptive use, pointing out the many ways that ecotourism consumes the environment, both literally and figuratively. 
and geographic scales (Campbell 2007). For example, the consumptive use of sea turtles in one country can be conceived as undermining protection efforts in another when sea turtles migrate between the two.

In common pool resource theory, the appropriate scale at which to manage resources, and concerns about the potential for scalar mismatches, has emerged as an important theme (Berkes 2006; Cumming, Cumming, and Redman 2006; Cash et al. 2006). Scalar mismatches occur when the scale of the ecological process and/or resource extraction occurs at wider or finer scales than associated governance institutions (Cumming, Cumming, and Redman 2006). Mismatches are particularly problematic for highly migratory marine resources, where the problem of exclusion (the ability of a group of resource users to exclude others) is amplified (Berkes 2006). Scalar mismatches are a central concern for sea turtle biologists, who question the ability of any one state to account for and manage these highly migratory animals (Campbell 2000; 2002). According to Berkes (2006), for migratory marine species, local and even national oversight is not enough: "an international agreement becomes necessary to solve the scale mismatch problem." Berkes recognizes, however, that attempts to resolve one set of scalar mismatches can create others. For example, that a resource is highly migratory does not negate the need for local level user groups to be involved in management; while local involvement in international agreements is theoretically possible, weak vertical linkages between scales can limit this potential (Berkes 2006) ${ }^{4}$. The scale issue is particularly complex in the Caribbean, where the dense concentration of many nations makes most resources by default shared and supports calls for international collaboration and management (Chakalall et al. 2007), but where the nature of governance institutions and limited potential for top-down enforcement by states supports calls for greater collaboration between states and resource users (Charles et al. 2007).

The question of scale is further complicated when we problematize the concept of scale itself, an issue of considerable interest to geographers and political ecologists. As Swyngedouw and Heynen (2003) describe it: "The continuous reorganisation of spatial scales is an integral part of social strategies to combat and defend control over limited resources and/or a struggle for empowerment." Brown and Purcell (2005) call for more attention to the "politics of scale" by political ecologists in particular; rather than taken as ontologically given, concepts of local, national, and international should be seen as socially constructed, both fluid and fixed, and as relational ideas. McCarthy (2005) calls for attention to environmental NGOs as participants in the politics of scale, and illustrates how they strategically both reinforce and challenge traditional concepts of scale, depending on the argument being made. Both Brown and Purcell (2005) and McCarthy (2005) highlight that questions about socio-political scale should not (and perhaps cannot) be separated from biophysical scale. For example,

\footnotetext{
${ }^{4}$ (Campbell, Godfrey, and Drif 2002) illustrate the difficulties fo integrating local communities into decision making in the Inter-American Convention for the Conservation of Sea Turtles.
} 
McCarthy argues that scale is produced "simultaneously by social processes and by biophysical processes that elude human control." But there is more to be said here. McCarthy (2005) and Brown and Purcell (2005) do not problematize our understanding biophysical processes and ecological scale, or the ways that these can also be constructed in support of particular scalar politics. For example, Campbell (2007) shows how scientists selectively employ ecological data to support predetermined conservation goals at particular socio-political scales, arguing that "promoting conservation action at a particular scale is not simply a matter of biological or ecological necessity, but serves the political interests of particular groups" (Campbell 2007). Further, Campbell (2007), Eden, Donaldson, and Walker (2006), Yearley (1996) and others have considered the relationship of science, scientists, and environmental NGOs, both how NGOs use science strategically and with what consequences; the line between NGOs and science is often blurred in conservation contexts (Campbell 2007). Thus, although both common pool resource theory and political ecology have interests in scale and scalar politics, we argue that insights from science studies can help us explore the ways in which science itself (i.e. the understanding of biophysical processes and ecology) is employed strategically in such politics by both scientists and NGOs.

\section{WHAT WE KNOW AND HOW WE KNOW IT: TECHNIQUES FOR UNDERSTANDING TURTLE BIOLOGY AND ECOLOGY}

Biological understanding of sea turtles, and the ability of such understanding to inform conservation policy, has traditionally been limited by the life history characteristics of sea turtles. Turtles are most accessible on the nesting beaches as adult females and as hatchlings. Our ability to study juveniles of both sexes and adult male turtles has been constrained by the difficulties of conducting inwater studies and because of the long distance migrations turtles make between nesting and foraging grounds. Hatchling turtles have been particularly problematic. Following their emergence from the nest and a 2-3 day 'swimming' frenzy to take them beyond coastal waters, hatchlings disappear for several years (called 'the lost year' ), when it is believed they passively drift in pelagic oceanic currents (Carr 1987). After an unknown period of time, they return inshore to foraging grounds as juveniles, where they can be more easily found and studied.

One of the main techniques for studying sea turtles and their movements has been by 'tagging', first using flipper tags (metal tags attached to flippers), then passive integrated transmitter (PIT) tags (inserted into the muscle of the turtle, and readable with a scanner), and more recently satellite telemetry tags (STT) (attached to the turtles carapace. Once attached, STTs transmit signals to satellites that return locational data that can be downloaded to a computer). While flipper and PIT tags have provided valuable information, this has primarily been on reproductively active adult females (e.g. when turtles tagged on nesting beaches are identified during subsequent nesting events throughout the season 
and over years, inter-seasonal and intra-annual nesting intervals can be calculated to estimate fecundity). In contrast, satellite tags have revolutionized our understanding of turtle movements (Godley et al. 2008). Post-nesting movements of adult females can be tracked, and sometimes reveal trans-ocean migrations and the time it takes to traverse these (Ferraroli et al. 2004). Overlaid with other oceanographic data, satellite tracks suggest relationships between things like sea surface temperature and migratory routes (e.g. Hawkes et al. 2007)). Male turtles and juveniles have also been tagged in water; prior to satellite tagging, these animals would have to be recaptured in-water to have their tags read, so few investments were made in tagging them with traditional techniques. Overall, ST tagging expands our understanding of 'habitat' beyond the nesting beach. In the language of Scott (1998), tracking makes turtles at sea, and to a certain extent the sea itself, legible.

While advances in tagging have greatly increased our understanding of individual turtles and their movements, small sample sizes and the absence of tracking data on hatchlings mean that conventional tagging is limited in how much it can reveal much about sea turtle populations (Godley et al. 2008), i.e. the relationships between animals found at various life stages in various places. Enter genetics. Genetic analyses have profound implications for the study and practice of conservation biology more generally. Some of the relevant areas in conservation that can be informed by genetics data include resolving population structure, defining management units within species, forensics, pedigree analysis, estimating population size and sex ratio (for a general overview, see DeSalle and Amato 2004). However, the application of genetics data to management actions is most powerful in combination with behavioral and demographic information (DeYoung and Honeycutt 2005).

In the case of sea turtles, gaps remain in the understanding of general demographic information for all species, including growth rates, age at sexual maturity, and survival rates (Heppell, Snover, and Crowder 2003). This in turn has limited somewhat the application of conservation genetics to sea turtles, although genetic analyses have illuminated a variety of different life-history questions, and genetics data have been invoked for conceptualizing "management units." For sea turtles, genetic studies have largely focused on mitochondrial DNA (mtDNA), which is maternally inherited, and look for unique markers (or haplotypes) along specific regions of mtDNA sequences. The elucidation of different haplotypes (or different ratios of haplotypes) from specific nesting rookeries of sea turtles is a powerful tool that has greatly increased our understanding of sea turtle biology and behavior. For instance, genetics data have proved a long-standing hypothesis that adult female sea turtles return to breed and lay eggs on or close to the beach where they were born, a process also known as natal homing (Meylan, Bowen, and Avise 1990; FitzSimmons et al. 1997; Dutton et al. 1999). Comparisons of haplotype diversity among sea turtle nesting assemblages has led to the conceptualization of different rookeries as independent management units (e.g. Schroth, Streit, and Schierwater 1996; 
FitzSimmons et al. 1997; Encalada et al. 1998), a concept central to our analysis below. ${ }^{5}$

Conservation biology in general has been defined as a discipline of 'crisis' and conservation biologists have debated the role of science versus advocacy for the discipline (Lackey 2007). Concerns about the use of misuse of science have been expressed on a variety of issues related to sea turtle conservation, including the use of genetics in distinguishing between different species of sea turtles. For example, there has long been debate about whether or not the green turtle (Chelonia mydas) found in the Pacific is a distinct species (Chelonia agassizi) (Mrosovsky 1983). In an exchange published in Conservation Biology, Peter Pritchard faced off against Brian Bowen and Steve Karl on this issue. Pritchard (1999) argued that morphologically, there were enough differences between Pacific and Atlantic green turtles to warrant the distinct species status, and that such status would be beneficial to conservation. Bowen and Karl (Bowen and Karl 1999; Karl and Bowen 1999) opposed this based their genetic analysis. What was most interesting about the exchange is the extent to which implications for conservation were explicitly addressed in a published forum. The establishment of the Pacific green as a distinct species essentially divides total green turtle population numbers; both the green and the black turtle would be categorized as more highly endangered since as separate populations they would be composed of fewer numbers. Karl and Bowen (1999) argued that the black turtle was a 'geopolitical' rather than taxanomic species, and claimed to have been pressured "to downplay or "reinterpret" genetic data on the evolutionary distinctiveness of the black turtle" (Bowen and Karl 1999) to serve conservation purposes.

In the example that follows, we explore how genetic data can be used to support claims to sea turtles outside and between national jurisdictions and in the ocean commons.

\section{GEO-POLITICAL GENETICS: HAWKSBILL SEA TURTLES IN THE CARIBBEAN}

One of the more contentious sea turtle conservation disputes has revolved around hawksbill turtles in the Caribbean. Hawksbills are listed as Critically Endangered by the IUCN (www.iucnredlist.org), and their depletion is has been driven by trade in the scutes that make up hawksbill carapaces, or what is known as tortoiseshell. Trade has been greatly reduced under CITES, but until 1992, trade continued between Japan and Cuba. Hawksbill shell is used by the Japanese Bekko industry to fashion art and cultural artifacts, and Japan maintained a reservation on hawksbill turtles under CITES to facilitate trade.

\footnotetext{
${ }^{5}$ Although there is evidence of male-mediated gene flow among these different management units (Roberts et al. 2004), the argument for the dominance of mtDNA data in defining management units is that natal homing exhibited by adult females implies that a rookery will not be re-established if all females are extirpated (Bowen and Karl 2007).
} 
Under pressure from the US, Japan removed this reservation in 1994, although they had stopped importing shell by the end of 1992. Since then, Cuba (with support from Japan) has twice presented proposals to CITES to transfer hawksbills from Appendix I to II in order to allow for limited and highly regulated trade in hawksbill shell with Japan (Prop 11.40, 11.41). Cuba presented biological studies of its hawksbill population (Carrillo, Webb, and Manolis 1999; Moncada et al. 1999), and the proposals included scientific justification of the management strategy, description of a registration system, mechanisms for channeling some profits to local communities, and mechanisms for adapting the harvest in the face of evidence of population decline. Under an approved Prop 11.40, Cuba would continue to harvest 500 individual hawksbill turtles, a voluntary reduction from the 2000 turtles harvested annually that was phased in over 1991 to 1995. Both proposals were defeated at the CITES CoP (only Prop 11.41 was voted on as Cuba withdrew Prop 11.40).

One issue at stake in debates over the Cuban harvest is the issue of 'ownership'. Given the migratory nature of sea turtles, opponents of the harvest argue that Cuba does not have the 'right' to harvest these animals, since doing so impinges on the rights of other countries who share the hawksbills. While resolving questions of 'ownership' is not listed as a contribution of genetic analyses in three recent review papers (DeSalle and Amato 2004; Hedrick 2001; DeYoung and Honeycutt 2005), this is exactly the type of argument that genetic data and analyses can inform. In 2007, Bowen et al. (2007a) published a review of hawksbill genetic studies conducted to date in the Caribbean, supplemented with new data from their own research, to provide a mixed-stock analysis of Caribbean hawksbill turtles. Mixed-stock analysis relies on genetic distinctiveness of source populations (in this case, nesting beaches) to determine the make-up of foraging stocks. Bowen et al. use samples from 10 nesting areas and 8 foraging areas and a total of 973 genetic samples (Table 1). Based on their analyses, Bowen et al. (2007a) claim that:

Harvest in the Caribbean foraging areas will deplete nesting populations across multiple jurisdictions... Therefore, hawksbill conservation embodies a conflict between national and international interests. International cooperation is the last and best hope (Bowen et al. 2007, 58).

Mortimer, Meylan, and Donnelly (2007) echo these claims. Citing Bowen et al. 2007, they argue that:

Harvests in any part of the Caribbean impact the species throughout the region. ... harvest of hawksbills from any nesting beach could impact multiple foreign feeding grounds, and that harvest on any feeding grounds could impact the nesting populations at multiple sites. Thus, any nation that opens or promotes harvest could be undermining badly needed efforts to conserve the species at other sites (Mortimer, Meylan, and Donnelly 2007, 18). 
As the above quotes illustrate, Bowen et al. (2007) and Mortimer, Meylan, and Donnelly (2007) use the understanding gained via genetic analyses to support claims that hawksbill sea turtles are regionally shared and should be managed as such. Further, they have specific views of what such management should entail; harvests will 'deplete' or 'impact' on regional populations and will undermine conservation. International cooperation (presumably to eliminate harvesting) is needed. In the following section, we use the results of Bowen et al.'s (2007) mixed-stock analysis to interrogate the veracity of claims regarding the regional nature of hawksbills, and to explore other potential claims that could be made based using the same data. Most of these claims are hypothetical (i.e. they have not been made by an existing party), but those that have circulated in the published literature are noted as such.

\section{Claim 1: Cuba harvests its own turtles}

Part of Cuba's argument in favor of a hawksbill harvest is that the harvest targets mostly 'Cuban' turtles, i.e. turtles that both nest on Cuban beaches and forage in Cuban waters. Although CITES proposals and published research from Cuba acknowledge that some immigration and emigration of hawksbill turtles occurs between Cuban waters and other areas of the Caribbean (Mrosovsky and Webb 1997; Carrillo, Webb, and Manolis 1999; Diaz-Fernandez et al. 1999), subsequent research on the implications of the Cuban hawksbill harvest have implied that Cuba claimed to be harvesting and managing a closed population (Bowen et al. 1996; Bowen and Karl 2007; Heppell and Crowder 1996). To what extent, then, is Cuba harvesting its own turtles? Of the 8 foraging grounds sampled by Bowen et al., 3 are in Cuba (A, B, D). Of all 8 sites sampled, Cuba A has the highest percentage of turtles originating from its own nesting beaches (over 70\%). Cuba B and D are also 'less mixed' than most other sites in the region, although over $50 \%$ of turtles foraging at $B$ and $D$ originate from nonCuban nesting beaches. Based on these figures, Cuba could support claims to continue harvesting at site $A$; more than $70 \%$ of the time, they are likely to be harvesting turtles coming from their own nesting beaches (we note that when Cuba reduced its harvest to 500 turtles, it focused its fishing efforts on site B).

Claim 2: Cuba's harvest decreases foraging populations throughout the region, even when the harvest targets turtles originating from Cuban beaches

Turtles from Cuba's nesting beaches contribute greatly to regional foraging stocks; they are the largest contributor to stocks at all sites sampled, except for Puerto Rico and Texas. On this basis, Bahamas, Dominican Republic, Puerto Rico and USVI could claim that, even though Cuba harvests mostly its own turtles, the harvest reduces the number of turtles in the population available to migrate to regional foraging areas. The argument would rely on assumptions about what might promote migration of Cuban foragers, for example, that emigration from Cuban waters might be driven by population density, in which 
case decreased density at Cuban foraging sites through harvesting might decrease migration to other sites.

\section{Claim 3: Fisheries in USVI or Puerto Rico impact on turtle nesting everywhere}

Of all foraging aggregations, USVI and Puerto Rico stocks are the most 'mixed', with 5 source populations contributing more than $10 \%$ each to the stock. Fisheries in those places could be contested as drawing on the conservation investments of several different countries, and undermining those countries' claims to the resources. Since there are no legal fisheries in USVI or Puerto Rico, such claims have not been articulated. However, there is a small sea turtle fishery in BVI, immediately adjacent to USVI (Campbell et al. in press). Assuming that genetic diversity sampled in USVI would not differ significantly from that in BVI, opponents of BVI's harvest could claim the harvest relies on and impacts nesting populations in five other countries. In contrast to the Cuban case, BVI has few nesting turtles of its own.

(mis)Claim 4: Reduced harvesting in Cuba has led to increased nesting in Barbados

Beggs, Horrocks, and Krueger (2007) describe increased nesting in Barbados, using data gathered from 1997-2004, and suggest that the reduction of Cuba's harvest in 1995, from 2000 to 500 turtles, contributes to this increase. While the authors are aware of Bowen et al.'s (2007a) work, and cite it elsewhere in their paper, Bowen et al.'s analysis does not support this claim. The mixed stock analysis of Cuba's foraging grounds finds little to no evidence of contributions from Barbadian beaches; thus, the reduction in the Cuban harvest is unlikely to have had an impact on Barbadian nesting numbers.

\section{COMPLICATING GENETICALLY BASED CLAIMS}

The claims outlined above, both hypothetical and real, are straightforward, based only on percentages associated with the mixed stock analysis. They become more complicated when other factors are taken into account, for example, nesting trends in source populations, the importance of genetic diversity, population dynamics, and conservation investments.

\section{Claims in light of nesting trends}

While hawksbill populations are considered greatly reduced it the Caribbean from a historical standpoint, there is evidence of recent contemporary increases based on trends in nesting on the region's beaches. Of the nesting beaches (source populations) sampled in Bowen et al. (2007a), nesting in Puerto Rico (Van Dam et al. 2008), Antigua (Richardson et al. 2006), and Barbados (Beggs, Horrocks, and Krueger 2007) is increasing. Nest trends in Mexico are fluctuating (increasing according to Garduño-Andrade et al. 1999); decreasing according to 
Abreu-Grobois et al. 2005), and decreasing in Costa Rica (Troëng, Dutton, and Evans 2005). Nest trends in Cuba and Belize are unknown. Overlaid with genetic data, nesting trends complicate resource claims. For example, while Puerto Rico contributes to all three of Cuba's foraging stocks, its nesting population is increasing (Van Dam et al. 2008). While recently documented increases may be associated with the decrease in the Cuban harvest in 1995, the ongoing harvest does not appear to be impairing nesting recovery in those places. In contrast, even though Costa Rica contributes only $12 \%$ of Cuba A's mixed stock, declined nesting in Costa Rica could support arguments that any take of these turtles, however low the percentage, impacts negatively on Costa Rica's nesting populations. In the latter case, a major decline appears to have occurred 50 years ago, with low level nesting since then (Troëng et al. 2005).

\section{Claims in light of genetic diversity}

Nesting populations are genetically distinctive; thus their use in defining management units. In the source populations considered in Bowen et al. (2007a), most are dominated by a single haplotype, with 2 or three others present in very small numbers (e.g. of 70 samples from Cuba's nesting population, the largest sample in the set, 62 are haplotype A, 5 are haplotype $\gamma$, and there are one each of haplotype F, Cu3, Cu4). In contrast, Puerto Rico has greater diversity. Of 35 samples, 13 are haplotype $F, 12$ are $N$, there are 2 each of $\mathrm{J}, \mathrm{L}, \mathrm{M}, \mathrm{O}$ and one each of $A$, and $K$ ). Haplotypes $\mathrm{J}, \mathrm{K}, \mathrm{L}, \mathrm{M}$ and $\mathrm{O}$ are all rare in the foraging populations throughout the region, so one could claim that regional foraging grounds where these haplotypes are found need to be better protected. Bowen et al. (2007a) argue that small contributions are relevant to conservation, an argument made more generally in conservation genetics; the loss of unique haplotypes can combine with declining trends in population sizes to reduce genetic variation within a population, and this in turn may lead to a decreased ability of a population to adapt in response to ecological challenges (DeSalle and Amato 2004). While this argument may be true, conservation biologists have debated the relative importance of population dynamics versus genetic diversity for conservation. The processes at stake in genetic extinction are believed to be much less important than more immediate impacts on populations.

\section{Claims in light of population dynamics}

While populations dynamics of sea turtles are not fully understood, Godfrey et al. (2007) challenge Bowen et al.'s (2007) assertion that their genetic data show that harvest in one country will be detrimental to conservation in another, based on a fundamental principle of wildlife management, namely that target populations can be harvested or culled without causing a decline in the overall population, due to density-dependent rates of growth (Getz and Haight 1989). While the question of what levels of harvesting can be withstood without harm to the overall population remain, Godfrey et al. (2007) point to some evidence of density-dependence in sea turtles (Bjorndal et al. 2000), and suggest that continued nesting increases in 
the region suggest that current harvests are likely under some maximum threshold past which they will no longer be sustainable. "Although the new phylogenetic data provided by Bowen et al. (2007) illuminate hawksbill migratory behaviour, they do not specifically inform us about sustainable levels of mortality of sea turtle populations" (Godfrey et al. 2007).

\section{Claims in light of conservation investment}

Reflecting the traditional focus of biological studies on nesting females, conservation efforts have also focused on nesting beaches and sometimes on adjacent waters. ${ }^{6}$ While there have long been debates about how best to protect sea turtles (Mrosovsky 1983; Frazer 1992), population modeling is useful in ranking the importance of different life stages to the status of a sea turtle population (Crouse, Crowder, and Caswell 1987). In particular, elasticity analyses suggest that management actions aimed at reducing mortality of large juveniles and adult turtles will have the greatest positive impact on sea turtle population dynamics (Crowder et al. 1994). While this has not curtailed efforts to eliminate mortality at other life stages (e.g. egg harvest), it does suggest that some conservation efforts are 'worth more' in terms of species productivity and conservation. Nesting beach protection is also economically costly, involving both direct costs (land purchase, protection, and monitoring), and the opportunity costs associated with taking that land and its resources out of production. Thus, investments in protection by countries like Costa Rica that has protected the nesting beach at Tortuguero since the 1970s could be used to 'weight' resource ownership claims.

\section{DISCUSSION}

Bowen et al. (2007) and Mortimer, Meylan, and Donnelley (2007) make the case for broadly based regional or international collaboration, given the stock mixing evident in the Caribbean. While we agree that their analysis shows the foraging stocks are often mixed, in some cases there are few countries involved and smaller scale regionalisms are likely at stake. For example, genetic data suggest that only USVI, Costa Rica, and Mexico make significant contributions to foraging aggregations in Cuba $A$, and those same countries contribute a higher proportion of turtles foraging at sites $B$ and $D$. In theory, a compromise agreement to eliminate harvesting at sites $B$ and $D$ while continuing a harvest turtles at Cuba $A$ might allay concerns about the impacts of Cuban harvesting on nesting populations in the three contributing countries. Whether or not this would be politically possible is another matter. The point is that the genetic data do not imply the whole region need be involved in this discussion, at least not genetic reasons (there may be other reasons for wider collaboration).

\footnotetext{
${ }^{6}$ Since the 1990s, there have been significant resources devoted to reducing the indirect negative impacts of fisheries on sea turtles (e.g. the incidental capture of sea turtles when fishing for other things).
} 
Regardless of what actual regionalisms are involved, here we turn to the issue of what is achieved through this particular science of sea turtles in terms of rights to resources and the scale at which conservation takes place. In this case, rights to resources are intimately tied to the issue of scale; if sea turtles are regional and internationally shared, than traditional rights of sovereign states to manage them independently can be challenged. But it's not as simple as this. As suggested by Bulkeley (2005), international environmental regimes both strengthen and weaken territorial sovereignty. Bowen et al.'s (2007a) work strengthens some state claims, like those of Costa Rica; data showing where turtles nesting and protected on Costa Rican beaches go can support Costa Rica's desires to influence conservation in those places. But Bowen et al.'s (2007) work is also used to weaken claims by states like Cuba, a state that contrary to trends in international sea turtle conservation has continued to harvest sea turtles and has petitioned for the right to trade sea turtles products internationally. What is important here is that the data themselves can support a variety of ownership claims; those that are strengthened and promoted are those that fall in line with goals of the international sea turtle conservation regime. The recent agreement by Cuba to end its sea turtle harvest after years of considerable international pressure illustrates that the reach of the global regime into sovereign state space (cf Bulkeley 2005) is clear, effective, and mostly unchallenged.

Similar to the implications of genetics for resource ownership claims, the implications of genetics for conservation are also subject to interpretation. For example, an argument in favor or Cuba's right to harvest hawksbill turtles at site A requires accepting that a small percentage of turtles captured there may not come from Cuba's nesting colony. It implies something about diversity, as there is a chance that some of the more rare haplotypes, e.g. those contributed by Costa Rica's source population, will be caught. Genetics alone cannot tell us whether or not particular outcomes are acceptable nor whether or they are ultimately sustainable. In the exchange between Godfrey et al. (2007) and Bowen et al. (2007b) on the implications of Bowen et al. (2007a) for sea turtle fisheries, a factor clearly influencing their different interpretations is their overall views of the potential for sustainable use in general; several of the authors involved in the exchange have taken opposing positions on this issue in a variety of other fora. Views of use are in turn influenced by a number of factors (e.g. attitudes to uncertainty, understanding of economics, values attached to turtles [Campbell 2000, 2002]).

The case of hawksbill genetics in the Caribbean also illustrates the importance and use of science in international environmental regimes. Molecular research is a highly technical and expensive research tool, and the language of genetic analysis is inaccessible to the non-geneticist:

Haplotype diversities among nesting locations were estimated with equation 8.4 of Nei (1987), as implemented in ARLEQUIN 3.0 (Excoffier et 
al. 2005). Nucleotide diversities, which estimate the mutation parameter $2 \mathrm{~N} \mu$, were calculated as $\theta \delta$ (Tajima 1983) in ARLEQUIN. AMOVA (ARLEQUIN) was used to partition the total haplotype variability among nesting colonies and among feeding aggregations. Sequence divergence between haplotypes was estimated under the Kimura 2-parameter model, following a gamma distribution with shape parameter $\alpha=0.50$ (Bowen et al. 2007a).

The level of technical skill required to analyze genetic samples and interpret their meaning supports in a concentration of expertise (at a few key labs in the USA and Europe) and leaves little room for outside critique ${ }^{7}$ or for combining local and expert knowledge in meaningful ways. While the science of genetics is somewhat inaccessible, the power in genetic arguments is compelling (a combination that may explain the misreading of Bowen et al. [2007] by Beggs et al. [2007]). Mortimer, Meylan, Donnelley (2007) pose the question 'whose turtles are they anyway?', but we suggest an equally important question is 'who gets to decide?' In a genetics based rights assignments, geneticists are the authorities working on behalf of global sea turtle conservation. The genetic identification of individual turtles as linked to particular nesting beaches appears to have superceded other means of claiming resources, e.g. territorial sovereignty, investments in conservation and management, geographic proximity, or history of use. While we may come to better understand sea turtles through genetics, any decision that this way of knowing is the best/only/natural one, and therefore the basis of management, is ultimately a human/political decision. As this paper suggests, such a decision has profound implications for how we envision rights to sea turtles as resources and the scale at which they should be managed.

\footnotetext{
${ }^{7}$ When one of our colleagues critiqued a genetics paper on the basis of limited sample sizes, the paper's author wrote to our colleague telling him he should not be commenting as he was not a geneticist; this is an excellent example of boundary work (Gieryn 1995) among scientists themselves.
} 
Table 1: Percentage contributions of source populations to juvenile hawksbill sea turtles on Caribbean feeding grounds, using maximum likelihood analysis (adapted from Bowen et al. 2007). Column headings refer to the feeding grounds where hawksbill turtles have been sampled in-water and the row headings refer to the nesting beaches. Reading down a column, we see what the genetic makeup of hawksbill turtles foraging in Bahamian waters is 37\% from Cuban nesting beaches, $4 \%$ from Puerto Rico, 25\% from USVI, 1\% from Antigua, 3\% from Costa Rica, and $28 \%$ from Mexico. In contrast, hawksbills foraging in Texan waters originate from USVI (7\%) and Mexico (93\%).

\begin{tabular}{|c|c|c|c|c|c|c|c|c|c|}
\hline & & \multicolumn{8}{|c|}{ Feeding grounds } \\
\hline & & Texas & Bahamas & Cuba A & Cuba B & Cuba D & DR & PR & USVI \\
\hline \multirow{9}{*}{ 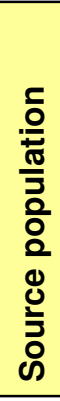 } & Cuba & 0.00 & 36.9 & 72.51 & 45.81 & 43.18 & 44.71 & 23.45 & 36.98 \\
\hline & PR & 0.00 & 3.96 & 0.01 & 15.69 & 10.74 & 1,82 & 11.06 & 14.66 \\
\hline & USVI & 6.64 & 25.39 & 6.59 & 25.18 & 7.87 & 19.99 & 39.54 & 15.31 \\
\hline & Antigua & 0.00 & 1.19 & 0.00 & .15 & 2.72 & 0.01 & 1.03 & 7.18 \\
\hline & Barbados & 0.00 & 0.00 & 0.04 & 0.00 & 0.00 & 0.14 & 0.00 & 0.05 \\
\hline & $\mathrm{CR}$ & 0.05 & 2.91 & 11.69 & 2.39 & 19.19 & 24.45 & 11.17 & 10.19 \\
\hline & Belize & 0.60 & 0.00 & 0.00 & 0.00 & 0.00 & 0.00 & 0.00 & 0.00 \\
\hline & Mexico & 92.71 & 28.37 & 6.83 & 9.88 & 14.52 & 6.66 & 13.04 & 12.69 \\
\hline & Unknown & 0.00 & 1.28 & 2.33 & .90 & 1.79 & 2,22 & 0.72 & 2.94 \\
\hline
\end{tabular}




\section{REFERENCES}

Abreu-Grobois FA, Guzman V, Cuevas E, Alba Gamio M (Compiladores). 2005. Memorias del Taller. Rumbo a la COP 3: Diagnóstico del estado de la carey (Eretmochelys imbricata) en la Península de Yucatán y determinacíon de acciones estratégicas. SEMARNAT, CONANP, IFAW, PRONATURA Península de Yucatán, WWF, Defenders of Wildlife. (Cited by Mortimer et al. 2007b)

Beggs, JA, JA Horrocks, and BH Krueger. 2007. Increase in hawksbill sea turtle Eretmochelys imbricata nesting in Barbados, West Indies. Endangered Species Research 3:159-168.

Berkes, F. 2006. From community-based resource management to complex systems: the scale issue and marine commons. Ecology and Society 11 (1):45.

Bjorndal, Karen A., and Alan B. Bolten. 2003. From Ghosts to Key Species: Restoring Sea Turtle Populations to Fulfill their Ecological Roles. Marine Turtle Newsletter 100:16-21.

Bowen, B. W., W. S. Grant, Z. Hillis-Starr, D . J. Shaver, K . A. Bjorndal, A. B. Bolten, and A. L. Bass. 2007. The advocate and the scientist: debating the commercial exploitation of endangered hawksbill turtles. Molecular Ecology 16 (17):3514-3515.

Bowen, B. W., W. S. Grant, Z. Hillis-Starr, D. J. Shaver, K. A. Bjorndal, A. B. Bolten, and A. L. Bass. 2007. Mixed-stock analysis reveals the migrations of juvenile hawksbill turtles (Eretmochelys imbricata) in the Caribbean Sea. Molecular Ecology 16 (1):49-60.

Bowen, B. W., and S. A. Karl. 2007. Population genetics and phylogeography of sea turtles. Molecular Ecology 16 (23):4886-4907.

Bowen, B.W., A.L. Bass, A. Garcia-Rodriguez, C.E. Diez, R. van Dam, A. B. Bolten, K.A. Bjorndal, M.M. Miyamoto, and R.J. Ferl. 1996. Origin of hawksbill turtles in a Caribbean feeding area as indicated by genetic markers. Ecological Applications 6 (2):566-572.

Bowen, B.W., and S.A. Karl. 1999. In War, Truth is the First Casualty. Conservation Biology 13 (5):1013-1016.

Brockington, Dan, Jim Igoe, and Kai Schmidt-Soltau. 2006. Conservation, human rights, and poverty reduction. Conservation Biology 20 (1):250-252. 
Broderick, AC, R Frauenstein, T George, F Glen, GC Hays, AD Jackson, GR Ruxton, and BJ Godley. 2006. Are green turtles globally endangered? . Global Ecology and Biogeography 15:21-26.

Brosius, J. P., and D. Russell. 2003. Conservation from above: an anthropological perspective on transboundary protected areas and ecoregional planning. Journal of Sustainable Forestry 17 (1/2):35-.

Brown, J. Christopher, and Mark Purcell. 2005. There's nothing inhernent about scale: political ecology, the local trap, and the politics of developmetn in the Brazilian Amazon. Geoforum 36:607-624.

Bulkeley, H. 2005. Reconfiguring environmental governance: Towards a politics of scales and networks. Political Geography 24 (8):875-902.

Campbell, Lisa M. 2007. Understanding human use of olive ridelys: implications for conservation. In Biology and conservation of ridley sea turltes, edited by P. T. Plotkin. Baltimore: The Johns Hopkins University Press.

- 2000. Human need in rural developing areas: perceptions of wildlife conservation experts. The Canadian Geographer 44 (2):167-181.

2002. Science and sustainable use: views of conservation experts. Ecological Applications 12 (4):1229-1246.

2003. Contemporary culture, use, and conservation of sea turtles. In The Biology of Sea Turtles, Volume II, edited by P. L. Lutz, J. A. Musick and J. Wyneken. Boca Raton: CRC Press.

2007. Reconciling local conservation practice with global discourse: a political ecology of sea turtle conservation. Annals of the Association of American Geographers 97 (2):313-334.

Campbell, Lisa M., Matthew H. Godfrey, and Ouissem Drif. 2002. Community based conservation via global legislation? Limitations of the InterAmerican Convention for Protection and Conservation of Sea Turtles. Journal of International Wildlife Law and Policy 5:121-143.

Campbell, Lisa M., Jennifer J. Silver, Noella J. Gray, Sue Ranger, Annette Broderick, Tatum Fisher, Matthew H. Godfrey, Shannon Gore, Karim V.D. Hodge, John Jeffers, Corrine Martin, Andrew McGowan, Peter Richardson, Carlos Sasso, Lorna Slade, and Brendan Godley. in press. Co-management of sea turtle fisheries: biogeography versus geopolitics. Marine Policy. 
Campbell, Lisa M., and Christina Smith. 2006. What makes them pay? Understanding values of conservation volunteers in Tortuguero, Costa Rica. Environmental Management 38 (1):84-98.

Carr, A. 1987. New perspectives on the pelagic stage of sea turtle development. Conservation Biology 1 (2):103-121.

Carrillo, C.E., G.J.W. Webb, and S.C. Manolis. 1999. Hawksbill turtles (Eretmochelys imbricata) in Cuba: an assessment of the historical harvest and its impacts. Chelonian Conservation and Biology 3 (2):264-280.

Cash, D. W., W. N. Adger, F. Berkes, P. Garden, L. Lebel, P. Olsson, L. Pritchard, and O. Young. 2006. Scale and cross-scale dynamics: governance and information in a multilevel world. Ecology and Society 11 (2):8.

Chakalall, B., R. Mahon, P. McConney, L. Nurse, and D. Oderson. 2007. Governance of fisheries and other living marine resources in the Wider Caribbean. Fisheries Research 87 (1):92-99.

Charles, A., S. Salas, R. Chuenpagdee, and J. C. Seijo. 2007. Evaluation and management of coastal fisheries in Latin America and the Caribbean Preface. Fisheries Research 87 (1):1-4.

Crouse, D.T., L.B. Crowder, and H. Caswell. 1987. A stage-based population model for loggerhead sea turtles and implication for conservation. Ecology 68:1412-1423.

Crowder, L.B., D.T. Crouse, S.S. Heppell, and T.H. Martin. 1994. Predicting the impact of turtle excluder devices on loggerhead sea turtle populations. Ecological applications 4:437-445.

Cumming, G. S., D. H. M. Cumming, and C. L. Redman. 2006. Scale mismatches in social-ecological systems: causes consequences, and solutions. Ecology and Society 11 (1):14.

DeSalle, R, and G. Amato. 2004. The expansion of conservation genetics Nature Reviews Genetics 5:702-712.

DeYoung, RW, and RL Honeycutt. 2005. The molecular toolbox: genetic techniques in wildlife ecology and management Journal of Wildlife Management 69:1362-1384.

Diaz-Fernandez, R. , T. Okayama, T. Uchiyama, E. Carrillo, G. Espinosa, R. Marquez, C. E. Diez, and H. Koike. 1999. Genetic sourcing for the 
hawksbill turtle, Eretmochelys imbricata, in the northern Caribbean region Chelonian Conservation and Biology 3:296-300.

Dutton, P.H., B. W. Bowen, D. W. Owens, A Barragan, and S.K. Davis. 1999. Global phylogeography of the leatherback turtle (Dermochelys coriacea). Journal of Zoology, London 248:397-409.

Eden, S., A. Donaldson, and G. Walker. 2006. Green groups and grey areas: scientific boundary-work, nongovernmental organisations, and environmental knowledge. Enivornment and Planning A 38:1061-1076.

Encalada, S.E., K.A. Bjorndal, A.B. Bolten, C.J. Zurita, B. Schroeder, E. Possardt, C.J. Sears, and B.W. Bowen. 1998. Population structure of loggerhead turtle (Caretta caretta) nesting colonies in the Atlantic and Mediterranean as inferred from mitochondrial DNA control region sequences. Marine Biology 130:567-575.

Ferraroli, S., J. Y. Georges, P. Gaspar, and Y. Le Maho. 2004. Where leatherbacks meet fisheries. Nature 429:521-522.

FitzSimmons, N.N., C. Moritz, C.J. Limpus, L. Pope, and R.I.T. Prince. 1997. Geographic structure of mitochondrial and nuclear gene polymorphisms in Australian green turtle populations and male-biased gene flow. Genetics 147:1843-1854.

Frazer, N.B. 1992. Sea turtle conservation and halfway technology. Conservation biology 6 (2):179-184.

Frazier, John G. 2003. Prehistoric and ancient historic interactions between humans and marine turtles. In The Biology of Sea Turtles, Volume II, edited by P. L. Lutz, J. A. Musick and J. Wyneken. Boca Raton: CRC Press.

2000. Building support for regional sea turtle conservation in ASEAN and the Asian region: leaning from the Inter-American Convention for the Protection and Conservaiton of Sea Turtles. In Sea Turtles of the IndoPacific, edited by N. Pilcher and G. Ismail. Sarawak, Malaysia: Institute of Biodiversity \& Environmental Conservation, University of Malaysia.

1999. Community-based conservation. In Research and Managment Techniques for the Conservation of Sea Turtles, edited by K. L. Eckert, K. A. Bjorndal, F. A. Abreu-Grobois and M. Donnelly: IUCN/SSC Marine Turtle Specialist Group.

Garduño-Andrade, M, V Guzman, E Miranda, R Briseño-Dueñas, and FA AbreuGrobois. 1999. Increases in hawksbill turtle (Eretmochelys imbricata) 
nesting in the Yucatan Peninsula, Mexico1977-1996: data in support of successful conservation. Chelonian Conservation and Biology 3:286-295.

Getz, W.M., and R.G. Haight. 1989. Population Harvesting: Demographic Models of Fish, Forest and Animal Resources. Princeton, New Jersey: Princeton University Press.

Gieryn, T. F. 1995. Boundaries of Science. In Handbook of Science and Technology Studies, edited by S. Jasanoff, G. E. Markle, J. C. Petersen and T. Pinch. London: Sage.

Godfrey, M. H., and B. J. Godley. 2008. Seeing past the red: flawed IUCN global listings for sea turtles. Endangered Species Research preprint:1-4.

Godfrey, M. H., Grahame J. W. Webb, S. Charlie Manolis, and N. Mrosovsky. 2007. Hawksbill sea turtles: can phylogenetics inform harvesting? Molecular Ecology 16 (17):3511-3513.

Godley, B. J., J. M. Blumenthal, A. C. Broderick, M. S. Coyne, M. H. Godfrey, L. A. Hawkes, and M. J. Witt1. 2008. Satellite tracking of sea turtles: Where have we been and where do we go next? Endangered Species Research 4:3-22.

Hawkes, L.A., A.C. Broderick, M.S. Coyne, M.H. Godfrey, and B.J. Godley. 2007. Only some like it hot - quantifying the environmental niche of the loggerhead sea turtle. Diversity and Distributions 13:445-457.

Hedrick, P.W. 2001. Conservation genetics: where are we now? Trends in Ecology \& Evolution 16:629-636.

Heppell, S. S., M. L. Snover, and L. B. Crowder. 2003. Sea turtle population ecology. In Biology Of Sea Turtles, edited by P. L. Lutz, J. A. Musick and J. Wyneken. Boca Raton, FL: CRC Press.

Heppell, S.S., and L.B. Crowder. 1996. Analysis of a fisheries model for harvest of hawksbill sea turtles (Eretmochelys imbricata). Conservation Biology 10 (3):874-880.

Karl, S.A., and B.W. Bowen. 1999. Evolutionary Significant Units Versus Geopolitical Taxonomy: Molecular Systematics of an Endangered Sea Turtle (genus Chelonia). Conservation Biology 13 (5):990-999.

Lackey, Robert T. 2007. Science, scientists, and policy advocacy. Conservation Biology 21 (1):12-17. 
McCarthy, J. 2005. Scale, sovereignty, and strategy in environmental governance. Antipode 37 (4):731-753.

McCormick, J. 1989. The global environmental movement: reclaiming paradise. London: Belhaven.

Meletis, Zoë, and Lisa M. Campbell. 2007. Call It Consumption! ReConceptualizing Ecotourism as Consumption and Consumptive. Geography Compass 1 (4):850-870.

Meylan, A. 1998. Hawksbill turtles still endangered. Nature 391:117.

Meylan, A.B., B.W. Bowen, and J.C. Avise. 1990. A genetic test of the natal homing versus social facilitation models for green turtle migration Science 248:724-727.

Moncada, F. , E. Carrillo, A. Saenz, and G Nodarse. 1999. Reproduction and nesting of the hawksbill turtle, Eretmochelys imbricata, in the Cuban archipelago. Chelonian Conservation and Biology 3 (2):257-263.

Mortimer, J. A., P.A. Meylan, and M Donnelly. 2007. Whose turtles are they, anyway? Molecular Ecology 16:17-18.

Mrosovsky, N. 1983. Conserving sea turtles. London: British Herpetological Society.

—. 1997. IUCN's credibility threatened. Nature 389:436.

- 2003. Predicting extinction: fundamental flaws in IUCN's Red List system, exemplified by the case of sea turtles:

http://members.seaturtle.org/mrosovsky/.

Mrosovsky, N., and Grahame Webb. 1997. Hawksbill Turtles in Cuba. Science $277(5327): 752$.

MTSG. 1995. A global strategy for the conservation of marine turtles. Gland Switzerland: IUCN.

Pritchard, P.C.H. 1999. Status of the Black Turtle. Conservation Biology 13 (5):1000-1003.

Richardson, JI, DB Hall, PA Mason, KM Andrews, R Bjorkland, Y Cai, and R Bell. 2006. Eighteen years of saturation tagging data reveal a significant increase in nesting hawksbill sea turtles (Eretmochelys imbricata) on Long Island, Antigua. Animal Conservation 9:302-307. 
Schroth, W., B. Streit, and B. Schierwater. 1996. Evolutionary handicap for turtles. Nature 384:521-522.

Scott, James C. 1998. Seeing like a state: how certain schemes to improve the human condition have failed. New Haven: Yale University Press.

Seminoff, J. A., and K. Shanker. 2008. Marine turtles and IUCN Red Listing: A review of the process, the pitfalls, and novel assessment approaches. Journal of Experimental Marine Biology and Ecology 356 (1-2):52-68.

Spotila, J. R., R. D. Reina, A. C. Steyermark, P. T. Plotkin, and F. V. Paladino. 2000. Pacific leatherback turtles face extinction. Nature 405 (6786):529530.

Swyngedouw, E., and N. C. Heynen. 2003. Urban political ecology, justice and the politics of scale. Antipode 35 (5):898-918.

Troëng, S., P. H. Dutton, and D. Evans. 2005. Migration of hawksbill turtles Eretmochelys imbricata from Tortuguero, Costa Rica. Ecography 28 (3):394-402.

Troëng, Sebastian, and Carlos Drews. 2004. Money talks: economic aspects of marine turtle use and conservation. Gland, Switzerland: WWFInternational.

Turtle Expert Working Group. 2007. An assessment of the leatherback turtle population in the Atlantic Ocean. In NOAA Technical Memorandum.

Van Dam, R. P. , C. E. Diez, G. H. Balazs, L. A. Colon Colon, W. O. McMillan, and B. A. Schroeder. 2008. Sex-specific migration patterns of hawksbill turtles breeding at Mona Island, Puerto Rico Endangered Species Research 4:85-94.

Webb, G.J.W., and E. Carrillo. 2000. Risk of extinction and categories of endangerment: perspectives from long-lived reptiles. Population Ecology 42:11-17.

Yearley, S. . 1996. Nature's advocates: putting science to work in environmental organisations. In Misunderstanding science? The public reconstruction of science and technology, edited by A. Irwin and B. Wynne. Cambridge: Cambride University Press. 